\title{
Kontribusi Kompetensi Profesional Dan Motivasi Kerja Terhadap Kinerja Guru
}

\author{
Kadek Diana Sintadewi ${ }^{1 *}$, Made Putra ${ }^{2}$ iD \\ 1,2 Jurusan Pendidikan Dasar, Universitas Pendidikan Ganesha, Singaraja, Indonesia \\ *Corresponding author: kadekdianasintadewi31@undiksha.ac.id
}

\begin{abstract}
Abstrak
Penelitian ini bertujuan untuk menganalisis kontribusi kompetensi profesional dan motivasi kerja terhadap kinerja guru. Penelitian ini merupakan penelitian expost-facto dengan menggunakan metode kuantitatif. Populasi dalam penelitian ini sebanyak 41 orang guru yang berstatus PNS. Untuk menentukan banyaknya sampel dalam penelitian ini menggunakan teknik non probability sampling yaitu teknik sampling total dan didapatkan sampel sebanyak 41 orang guru PNS. Metode pengumpulan data menggunakan metode non tes. Metode non tes yang digunakan adalah kuesioner untuk mengukur kompetensi professional dan motivasi kerja serta menggunakan metode pencatatan dokumen berupa nilai kinerja guru. Teknik analisis data menggunakan analisis uji prasyarat yaitu uji normalitas, uji linearitas, uji multikolinearitas dan uji heterokedastisitas. Untuk pengujian hipotesis menggunakan uji regresi linear sederhana dan uji regresi linear ganda. Dari hasil analisis diperoleh bahwa terdapat kontribusi yang signifikan kompetensi profesional terhadap kinerja guru sebesar $33,2 \%$, terdapat kontribusi yang signifikan motivasi kerja terhadap kinerja guru sebesar $35,7 \%$ dan terdapat kontribusi kompetensi profesional dan motivasi kerja terhadap kinerja guru sebesar 42,6\%. Dapat disimpulkan bahwa terdapat kontribusi yang signifikan kompetensi profesional dan motivasi kerja terhadap kinerja guru.
\end{abstract}

Kata kunci: Kinerja Guru, Kompetensi Profesional, Motivasi Kerja

\section{Abstract}

This study aims to analyze the contribution of professional competence and work motivation to teacher performance. This research is an expost-facto research using quantitative methods. The population in this study were 41 teachers who were civil servants. To determine the number of samples in this study using non-probability sampling techniques, namely total sampling techniques and obtained a sample of 41 civil servant teachers. Methods of data collection using non-test method. The non-test method used was a questionnaire to measure professional competence and work motivation and used a document recording method in the form of teacher performance scores. The data analysis technique used prerequisite test analysis, namely normality test, linearity test, multicollinearity test and heteroscedasticity test. To test the hypothesis using a simple linear regression test and multiple linear regression test. From the results of the analysis, it was found that there was a significant contribution of professional competence to teacher performance of $33.2 \%$, there was a significant contribution of work motivation to teacher performance of $35.7 \%$ and there was a contribution of professional competence and work motivation to teacher performance of $42.6 \%$. It can be concluded that there is a significant contribution of professional competence and work motivation to teacher performance.

Keywords: Teacher Performance, Professional Competence, Work Motivation

$\begin{array}{lll}\text { History: } & \text { Publisher: Undiksha Press } \\ \text { Received } & \text { : 4 Januari } 2021 & \text { Licensed: This work is licensed under } \\ \text { Revised } & : \text { 16 Februari } 2021 & \text { a Creative Commons Attribution 4.0 License } \\ \text { Accepted : } 5 \text { Maret } 2021 & \text { CC () } \\ \text { Published : 25 Maret } 2021 & \end{array}$

\section{Pendahuluan}

Sumber daya manusia (SDM) merupakan faktor yang memiliki peran yang sangat penting di dalam suatu negara. Pada era globalisasi saat ini, setiap negara menginginkan untuk memiliki sumber daya manusia yang berkualitas yang memiliki inovatif dan kreatif 
agar dapat menghadapi persaingan-persaingan dengan negara lain. Untuk mencipatakan sumber daya manusia yang berkualitas dibutuhkan sistem pendidikan yang bermutu. Kegiatan pembelajaran di sekolah memiliki peran yang sangat penting karena pembelajaran di sekolah akan menentukan kualiats yang dimiliki oleh peserta didik. Mutu pendidikan dipengaruhi oleh beberapa komponen salah satunya adalah guru (Sopandi, 2019). Seorang guru dalam sistem pendidikan merupakan salah satu komponen yang mendukung terlaksananya pendidikan karena guru langsung berinteraksi dengan peserta didik sehingga guru memiliki peran yang begitu besar dalam menciptakan sumber daya manusia yang berkualitas (Widiansyah, 2018). Berdasarkan hal tersebut untuk meningkatkan mutu pendidikan tidak akan dapat berpengaruh tanpa peran guru yang memiliki kinerja yang optimal (Sya'roni, Herlambang, T., \& Cahyono, 2018). Kinerja guru dalam pembelajaran ialah faktor utama untuk mewujudkan tujuan pendidikan karena guru adalah ujung tombak dalam sistem pendidikan (Priyono, B. H., Qomariah, N., \& Winahyu, 2018).

Kinerja guru merupakan kemampuan seorang guru dalam melakukan suatu pekerjaan sesuai dengan tujuan yang telah ditetapkan (Pratiwi et al., 2021). Dengan kinerja guru yang profesional diharapkan dapat mewujudkan keberhasilan dalam dunia pendidikan dengan mewujudkan tujuan pendidikan nasional(Anwar, 2020). Dalam proses pembelajaran kinerja guru meliputi kinerja guru dalam perencanaan, kinerja guru dalam proses pelaksanaan pembelajaran dan kinerja guru dalam evaluasi pembelajaran (Sodik et al., 2019). Namun, permasalahan yang biasanya terjadi di bidang pendidikan ialah kinerja guru. Jika kinerja guru tidak diperhatikan maka akan berdampak pada kualitas yang dimiliki oleh peserta didik. Faktor yang dapat mempengaruhi kinerja guru ialah belum optimalnya kompetensi guru dan dorongan dalam bekerja (Hartanti \& Yuniarsih, 2018). Jadi, kinerja guru ialah kunci dari kesuksesan demi mewujudkan tujuan pendidikan (Immah, F., Sukidin, S., \& Kartini, 2020). Berbagai faktor yang menyebabkan guru kurang profesional dalam menjalankan tugas dan tanggung jawabnya salah satu adalah pendidikan, pemimpin, pengalaman kerja, kompetensi, kemampuan, motivasi kerja yang dimiliki oleh guru tersebut dan lain sebagainya (Supriyono, 2017).

Kompetensi guru merupakan suatu keterampilan, wawasan dan pengetahuan yang harus dikuasai secara mendalam oleh guru untuk mengimpelementasikan dalam proses pembelajaran (Syaidah, 2018). Adapun empat kompetensi guru yaitu kompetensi pedagogik, kompetensi kepribadian, kompetensi sosial dan kompetensi profesional (Giantoro, H. M., Haryadi, H., \& Purnomo, 2019; Sopandi, 2019). Salah satu kompetensi yang harus dimiliki oleh guru sebagai profesi adalah kompetensi profesional karena kompetensi profesional langsung berhubungan dengan kinerja guru yang ditampilkan (Giantoro, H. M., Haryadi, H., \& Purnomo, 2019; Supriyono, 2017). Jadi, menjadi seorang guru harus memiliki kompetensi profesioanal karena dengan memiliki kompetensi profesional guru akan menghasilkan proses pembelajaran yang optimal. Sehingga guru dapat menghasilkan kinerja yang optimal. Selain itu, seorang guru juga sering kurang semangat dalam bekerja, hal ini disebabkan karena kurangnya motivasi kerja sehingga kinerja guru kurang optimal (Kartini, D., \& Kristiawan, 2019). Seorang guru yang mempunyai motivasi yang tinggi dalam melakukan pekerjaan guru akan memiliki suatu dorongan dan semangat untuk melaksanakan tugasnya dengan optimal (Patarai et al., 2018; Pratiwi et al., 2021). Oleh karena itu, kinerja guru sangat dipengaruhi oleh motivasi kerja yang dimiliki oleh guru untuk melaksanakan tugasnya dalam proses pembelajaran agar dapat mencapai tujuan pendidikan yang telah ditetapkan.

Temuan penelitian berkaitan dengan kompetensi professional terhadap guru. Semakin tinggi kompetensi pedagogik, profesional, dan motivasi kerja, maka kinerja guru juga tinggi dalam mencapai tujuan pendidikan (Supriyono, 2017). Kompetensi professional dan motivasi kerja memiliki pengaruh positif signifikan terhadap kinerja guru (Hartanti \& Yuniarsih, 2018). Temuan penelitian terkait motivasi mengajar, kompetensi professional, 
dan tingkat pendidikan berpengaruh positif dan signifikan secara simultan terhadap kinerja guru di SMK Negeri 4 Soppeng (Patarai et al., 2018). Maka dari itu, dalam penelitian ini difokuskan pada kinerja guru yang dipengaruhi oleh kompetensi profesional dan juga motivasi kerja. Selain itu, temuan penelitian yang menyatakan pengawasan, disiplin dan motivasi berpengaruh positif dan signifikan terhadap kinerja guru SD Negeri Dinas Pendidikan UPT Kecamatan Medan Area Kota Medan (Rivai, 2021).

Berdasarkan permasalahan tersebut, penelitian ini bertujuan untuk mengetahui besaran kontribusi kompetensi profesional terhadap kinerja guru, untuk mengetahui besaran kontribusi motivasi kerja terhadap kinerja guru dan untuk mengetahui besaran kontribusi kompetensi profesional dan motivasi kerja terhadap kinerja guru.

\section{Metode}

Penelitian ini menggunakan metode kuantitatif dengan tidak memanipulasi atau memberi perlakuan terhadap variabel bebas sehingga penelitian ini disebut dengan penelitian ex-post facto. Populasi dalam penelitian ini adalah guru-guru yang terlibat langsung dalam kegiatan proses pembelajaran yang berhadapan langsung dengan peserta didik dan yang berstatus sebagai Pegawai Negeri Sipil (PNS). Jumlah guru yang berstatus PNS di SD Gugus III Mengwi yang terdiri dari 7 sekolah yang berjumlah 41 guru PNS. Adapun, teknik untuk menentukan besarnya jumlah sampel adalah mengunakan teknik non probability sampling yaitu teknik sampling total. Mengingat jumlah populasi yang tidak terlalu besar dan kurang dari 100 orang, maka sampel menggunakan keseluruhan dari jumlah populasi. Metode pengumpulan data yang digunakan ialah metode non tes yang berupa kuesioner atau angket dengan skala likert 1 - 4 dan pencatatan dokumen. Teknik analisis data dalam penelitian ini menggunakan teknik analisis statistik deskriptif dan statistik inferensial. Statistik deskriptif yang digunakan untuk mendseskripsikan data dengan menghitung rata-rata (mean), modus, median, varians dan standar deviasi. Statistika inferensial ini digunakan untuk menguji hipotesis dalam penelitian. Sebelum melakukan uji hipotesis, dilakukan uji prasyarat terlebih dahulu, yaitu uji normalitas, uji linearitas, uji multikolinearitas dan uji heterokedastisitas. Untuk uji hipotesis menggunakan uji regresi linear sederhana dan uji regresi linear ganda.

\section{Hasil dan Pembahasan \\ Hasil}

Hasil penelitian ini akan mendeskripsikan data mengenai kinerja guru sebagai variabel terikat $(\mathrm{Y})$, kompetensi profesional $\left(\mathrm{X}_{1}\right)$ dan motivasi kerja $\left(\mathrm{X}_{2}\right)$, adapun penjelasannya sebagai berikut.

Tabel 1. Deskripsi Data Kinerja Guru, Kompetensi Profesional dan Motivasi Kerja

\begin{tabular}{cccc}
\hline Deskripsi Data & Kinerja Guru & $\begin{array}{c}\text { Kompetensi } \\
\text { Profesional }\end{array}$ & Motivasi Kerja \\
\hline Sampel & 41 & 41 & 41 \\
Skor Maksimum & 92,86 & 144 & 146 \\
Skor Minimum & 80,36 & 107 & 110 \\
Rata-rata (Mean) & 87,334 & 123,256 & 124,939 \\
Median & 89,179 & 123,858 & 122,1 \\
Modus & 88,575 & 125,502 & 119,167 \\
Varians & 9,878 & 74,309 & 83,264 \\
Standar Deviasi & 3,143 & 8,620 & 9,125 \\
\hline
\end{tabular}


Berdasarkan hasil analisis data menunjukkan secara umum rata-rata skor kinerja guru diperoleh sebesar 87,334 dengan simpangan baku (standar deviasi) sebesar 3,143. Hasil ini menunjukkan bahwa kecenderungan kinerja guru dapat dikategorikan baik. Hasil analisis data menunjukkan rata-rata skor variabel kompetensi professional diperoleh sebesar 123,256, dengan simpangan baku (standar deviasi) sebesar 8,620. Hasil ini menunjukkan bahwa kompetensi profesional dapat dikategorikan sangat baik. Hasil analisis data secara umum skor rata-rata motivasi kerja diperoleh sebesar 124,939 dengan simpangan baku (standar deviasi) sebesar 9,125. Hasil ini menunjukkan bahwa kecenderungan motivasi kerja dapat dikategorikan sangat baik. Dalam penelitian ini, terdapat empat uji prasyarat, yaitu uji normalitas, uji linearitas, uji multikolonieritas dan uji heterokedastisitas.

Tabel 2. Uji Normalitas

\begin{tabular}{lccc}
\hline \multicolumn{1}{c}{ Residual Variabel } & $\begin{array}{c}\text { KS } \\
\left|F_{T}-F_{S}\right|\end{array}$ & KS $_{\text {tabel }}$ & Keterangan \\
\hline $\begin{array}{l}\text { Kompetensi Profesional terhadap } \\
\text { Kinerja Guru }\left(\mathrm{X}_{1} \mathrm{Y}\right)\end{array}$ & 0,0537 & 0,212 & Berdistribusi normal \\
$\begin{array}{l}\text { Motivasi Kerja terhadap Kinerja Guru } \\
\left(\mathrm{X}_{2} \mathrm{Y}\right)\end{array}$ & 0,0665 & 0,212 & Berdistribusi Normal \\
$\begin{array}{l}\text { Kompetensi Profesional dan Motivasi } \\
\text { Kerja terhadap Kinerja Guru }\left(\mathrm{X}_{1} \mathrm{X}_{2} \mathrm{Y}\right)\end{array}$ & 0,0653 & 0,212 & Berdistribusi Normal \\
\hline
\end{tabular}

Berdasarkan hasil uji normalitas dengan menggunakan rumus Kolmogorov-Smirnov. Berdasarkan perhitungan, didapatkan data hasil uji normalitas yang menggunakan nilai residual data kompetensi profesional $\left(\mathrm{X}_{1}\right)$ terhadap kinerja guru $(\mathrm{Y})$ diperoleh hasil $\left|F_{T}-F_{S}\right|=0,0537$ dan $\mathrm{Ks}_{\text {tabel }}=0,212$, hal tersebut berarti bahwa data kompetensi profesional $\left(\mathrm{X}_{1}\right)$ terhadap kinerja guru berdistribusi normal. Kemudian, uji normalitas yang menggunakan nilai residual data motivasi kerja $\left(\mathrm{X}_{2}\right)$ terhadap kinerja guru $(\mathrm{Y})$ diperoleh hasil $\left|F_{T}-F_{S}\right|=0,0665$ dan $\mathrm{Ks}_{\text {tabel }}=0,212$, hal tersebut berarti bahwa data motivasi kerja $\left(\mathrm{X}_{2}\right)$ terhadap kinerja guru berdistribusi normal.

Tabel 3. Uji Linearitas

\begin{tabular}{cccc}
\hline Variabel & F $_{\text {hitung }}$ & F tabel & Keterangan \\
\hline $\begin{array}{c}\text { Kompetensi Profesional terhadap Kinerja Guru } \\
\left(\mathrm{X}_{1} \mathrm{Y}\right)\end{array}$ & 1,835 & 2,244 & Linear \\
Motivasi Kerja terhadap Kinerja Guru $\left(\mathrm{X}_{2} \mathrm{Y}\right)$ & 0,629 & 2,208 & Linear \\
\hline
\end{tabular}

Berdasarkan perhitungan tersebut, maka mendapatkan hasil untuk kompetensi profesional terhadap kinerja guru adalah $F_{\text {hitung }}=1,835$ lebih kecil dari pada $F_{\text {tabel }}=2,244$ pada taraf signifikansi $5 \%(0,05)$ sehingga dinyatakan bahwa kompetensi profesional terhadap kinerja guru bersifat linear. Sedangkan, untuk motivasi kerja terhadap kinerja guru adalah $F_{\text {hitung }}=0,629$ lebih kecil dari pada $F_{\text {tabel }}=2,208$ pada taraf signifikansi 5\% $(0,05)$ sehingga dinyatakan bahwa motivasi kerja terhadap kinerja guru bersifat linear.

Berdasarkan hasil perhitungan Tabel 4, menyatakan bahwa nilai Tolerance untuk kompetensi profesiona dan motivasi kerja sebesar $=0,619$ yang berarti mendekati atau kurang dari 1 dan nilai VIF untuk kompetensi profesional dan motivasi kerja sebesar = 1,615 yang berarti kurang dari 10. Jadi, berdasarkan hal tersebut disimpulkan bahwa di antara variabel bebas tidak terjadi multikolinearitas. 
Tabel 4. Uji Multikolinearitas

\begin{tabular}{cccc}
\hline Variabel & Tolerance & VIF & Keterangan \\
\hline Kompetensi Profesional $\left(\mathrm{X}_{1}\right)$ & 0,619 & 1,615 & Tidak Terjadi Multikolinearitas \\
Motivasi Kerja $\left(\mathrm{X}_{2}\right)$ & 0,619 & 1,615 & Tidak Terjadi Multikolinearitas \\
\hline
\end{tabular}

Tabel 5. Uji Heterokedastisitas

\begin{tabular}{ccc}
\hline Variabel & Sig & Keterangan \\
\hline Kompetensi Profesional $\left(\mathrm{X}_{1}\right)$ & 0,172 & Tidak Terjadi Heterokedastisitas \\
Motivasi Kerja $\left(\mathrm{X}_{2}\right)$ & 0,456 & Tidak Terjadi Heterokedastisitas \\
\hline
\end{tabular}

Dalam pengujian heterokedastisitas diperoleh nilai signifikan variabel kompetensi profesional $\left(\mathrm{X}_{1}\right)$ ialah 0,172 yang melebihi 0,05 hal tersebut disimpulkan bahwa tidak terjadi heterokedastisitas. Sedangkan, pada variabel motivasi kerja $\left(\mathrm{X}_{2}\right)$ adalah 0,456 yang melebihi 0,05 hal tersebut disimpulkan bahwa tidak terjadi heterokedastisitas.

\section{Pembahasan}

Berdasarkan uji prasyarat yang telah dilakukan sebelumnya, seluruh persyaratan pengujian dengan analisis regresi sudah terpenuhi. Berdasarkan hal tersebut analasis regresi untuk pengujian hipotesis dapat dilaksanakan. Hipotesis I dan II digunakan uji regresi linear sederhana serta pengujian hipotesis III digunakan uji regresi linear ganda.

Hasil penelitian menemukan bahwa terdapat kontribusi yang signifikan kompetensi profesional dan motivasi kerja terhadap kinerja guru di SD Gugus III Mengwi Tahun Ajaran 2020/2021. Dapat dilihat dari aspek kemampuan yang dimiliki guru. Kompetensi profesional guru dimiliki berdasarkan kemampuan penguasaan materi pelajaran secara luas dan mendalam. Pengembangan keprofesian, melalui pendidikan dan kegiatan pelatihan, seminar, workhsop, publikasi ilmiah, serta karya inovatif sebagai pengembangan dirinya. Guru yang memiliki kompetensi profesional yang tinggi terbukti menguasai pengetahuan dalam bidang IPTEKS serta mampu menyelesaikan tugas-tugas keseharian dalam mengelola pembelajaran di kelas sehingga menghasilkan kinerja yang tinggi (Dudung, 2018; Supriyono, 2017).

Jika dilihat dari motivasi kerja guru saat menjalankan tugas yang masih kurang. dikarenakan sarana dan prasana guru dalam mengajar belum terpenuhi secara layak. Berdasarkan uraian tersebut, maka sangat perlu peningkatan motivasi. Peningkatan motivasi ini memiliki tujuan agar guru dapat melaksanakan tugas dengan maksimal dan mencapai kinerja yang optimal. Kinerja guru akan meningkat apabila motivasi guru lebih ditingkatkan lagi. Motivasi menjadi dorongan yang dimiliki, baik secara intrinsik maupun ekstrinsik untuk mengarahkan segala kemampuannya agar mencapai tujuan dan berbagai sasarannya (Rivai, 2021; Rizal, 2019). Beberapa temuan juga menunjukkan terdapat pengaruh yang signifikan motivasi terhadap kinerja guru(Effendi \& Yogie, 2019; Farhah et al., 2020).

Hal tersebut menunjukan hubungan yang sangat kuat antara kompetensi profesional dan motivasi kerja terhadap kinerja guru. Hal ini dapat dilihat dari kompetensi yang dimiliki guru dan motivasi yang masih kurang. Kompetensi dan motivasi kerja guru dapat diperkuat dengan sertifikasi pendidik. Dengan sertifikasi pendidik diharapkan guru yang bekerja sudah sesuai dengan latar belakang dan kualifikasi jenjang pendidikannya. Semakin tinggi kompetensi pedagogik, profesional, dan motivasi kerja, maka kinerja guru juga tinggi dalam mencapai tujuan pendidikan (Indriyani \& Suparjo, 2018; Salmawati et al., 2017; Supriyono, 2017)

Hasil penelitian ini mendukung temua penelitian mengenai kompetensi professional dan motivasi terhadap kinerja guru. Kompetensi professional dan motivasi kerja memiliki pengaruh positif signifikan terhadap kinerja guru (Darwis et al., 2019; Hartanti \& Yuniarsih, 
2018; Patarai et al., 2018; Rivai, 2021; Sopandi, 2019). Beberapa temuan tersebut menunjukkan adanya kontribusi kompetensi professional dan motivasi pada guru jenjang SMP, SMK. Setelah dilakukan penelitian di SD ternyata kompetensi professional dan motivasi sangat berkontribusi juga terhadap kinerja guru sekolah dasar. Maka dari itu, dalam penelitian ini difokuskan pada kinerja guru yang dipengaruhi oleh kompetensi profesional dan juga motivasi kerja di sekolah dasar

\section{Simpulan}

Berdasarkan hasil penelitian dan pembahasan yang telah dipaparkan, dapat disimpulkan bahwa terdapat kontribusi yang signifikan kompetensi profesional terhadap kinerja guru, terdapat kontribusi yang signifikan motivasi kerja terhadap kinerja guru dan terdapat kontribusi yang signifikan kompetensi profesional dan motivasi kerja terhadap kinerja guru. Dari kontribusi masing-masing variabel tersebut berarti bahwa masing-masing variabel saling menguatkan dalam meningkatkan kinerja guru. Dengan demikian dapat disimpulkan bahwa semakin meningkat kompetensi profesional dan motivasi kerja maka kinerja guru juga akan meningkat. Hasil penelitian, guru disarankan dapat meningkatkan kompetensi profesionalnya dan meningkatkan motivasi kerja. Kepala sekolah disarankan untuk selalu memberikan perhatian kepada seluruh guru, seperti selalu mengadakan pembinaan terhadap kemampuan guru dalam menjalankan tugasnya, selalu memberikan penghargaan atau reward setiap guru yang memiliki prestasi. Kepada penelitian disarankan agar hasil penelitian ini dapat dimanfaatkan sebagai referensi pelaksanaan penelitian selanjutnya dan bermanfaat bagi seluruh peneliti yang menjadikannya sebagai rujukan.

\section{Daftar Rujukan}

Anwar, A. S. (2020). Pengembangan Sikap Profesionalisme Guru Melalui Kinerja Guru Pada Satuan Pendidikan Mts Negeri 1 Serang. Andragogi: Jurnal Pendidikan Islam Dan Manajemen Pendidikan Islam, 2(1), 147-173. https://doi.org/10.36671/andragogi.v2i1.79.

Darwis, M., Batari, U. D., Salam, R., Kasmita, M., \& Baharuddin, A. (2019). Pengaruh Kompetensi Profesional Guru Terhadap Kualitas Proses Pembelajaran Pada Paket Keahlian Administrasi Perkantoran Di SMK Negeri 1 Gowa. Jurnal Ad'ministrare, 5(2), 105. https://doi.org/10.26858/ja.v5i2.7889.

Dudung, A. (2018). Kompetensi Profesional Guru (Suatu Studi Meta-Analysis Desertasi Pascasarjana UNJ). Jurnal Kesejahteraan Keluarga Dan Pendidikan, 5(1), 9-19.

Effendi, M., \& Yogie, F. (2019). Pengaruh Motivasi dan Disiplin Kerja terhadap Kinerja Karyawan. Journal of Management and Bussines (JOMB), 1(1), 88-98. https://doi.org/10.31539/jomb.v1i1.654.

Farhah, A., Ahiri, J., \& Ilham, M. (2020). Pengaruh Motivasi Kerja Dan Disiplin Kerja Terhadap Kinerja Karyawan. Jurnal Online Program Studi Pendidikan Ekonomi, 5(1), 1. https://doi.org/10.36709/jopspe.v5i1.13326.

Giantoro, H. M., Haryadi, H., \& Purnomo, R. (2019). Pengaruh Kompetensi Guru, Kepemimpinan Kepala Sekolah Menurut Persepsi Guru Dan Motivasi Kerja Terhadap Kinerja Guru Smk Negeri Di Kabupaten Purbalingga. Jurnal Ekonomi, Bisnis, Dan Akuntansi, 21(2). https://doi.org/10.32424/jeba.v21i2.1290.

Hartanti, A. S., \& Yuniarsih, T. (2018). Pengaruh Kompetensi Profesional Guru dan Motivasi Kerja Terhadap Kinerja Guru Di Sekolah Menengah Kejuruan. Jurnal Pendidikan Manajemen Perkantoran, 3(1), 167. https://doi.org/10.17509/jpm.v3i1.9452.

Immah, F., Sukidin, S., \& Kartini, T. (2020). Pengaruh Kompetensi Profesional Guru Terhadap Kinerja Guru Di Sma Negeri 01 Kalisat Tahun Pelajaran 2018/2019. Jurnal 
Ilmiah Ilmu Pendidikan, Ilmu Ekonomi Dan Ilmu Sosial, 14(1), 253. https://doi.org/10.19184/jpe.v14i1.12493.

Indriyani, Y., \& Suparjo. (2018). Pengaruh Kompetensi Pedagogik , dan Motivasi Kerja Terhadap Kinerja Guru SMK Bhakti Praja Kabupaten Batang. Serat Acitya - Jurnal Ilmiah UNTAG Semarang, 7(2), 88-101.

Kartini, D., \& Kristiawan, M. (2019). Pengaruh Tunjangan Profesi dan Motivasi Kerja Terhadap Kinerja Guru. Jurnal Manajemen Pendidikan, 6(1), 25-33. https://doi.org/10.24246/j.jk.2019.v6.i1.p25-33.

Patarai, I., Mustari, \& Azis, M. (2018). Motivasi Mengajar, Kompetensi Profesional dan Tingkat Pendidikan terhadap KInerja Guru. Jurnal Mirai Management, 3(2), 120133. https://doi.org/10.1234/mirai.v3i2.269.

Pratiwi, W. A., Prasetyo, I., \& Shabrina, M. N. (2021). Faktor-Faktor yang Berpengaruh terhadap Kinerja Guru Taman Kanak-Kanak. 5(2), 1741-1753. https://doi.org/10.31004/obsesi.v5i2.970.

Priyono, B. H., Qomariah, N., \& Winahyu, P. (2018). Pengaruh Gaya Kepemimpinan, Motivasi Guru Dan Lingkungan Kerja Fisik Terhadap Kinerja Guru Sman 1 Tanggul Jember. Jurnal Manajemen Dan Bisnis Indonesia, 4(2), 144. https://doi.org/10.32528/jmbi.v4i2.1758.

Rivai, A. (2021). Pengaruh Pengawasan, Disiplin dan Motivasi Terhadap Kinerja Guru. Maneggio: Jurnal Ilmiah Magister Manajemen, 4(1), 11-22. http://jurnal.umsu.ac.id/index.php/MANEGGIO/article/view/6715.

Rizal, A. S. (2019). Pengaruh Motivasi Kerja Dan Kedisiplinan Terhadap Kinerja Guru Smp. Jurnal Ulul Albab, 23(1), 15. https://doi.org/10.31764/jua.v23i1.658.

Salmawati, Rahayu, T., \& Lestari, W. (2017). Kontribusi Kompetensi Pedagogik , Kompetensi Profesional dan Motivasi Kerja terhadap Kinerja Guru Penjasorkes SMP di Kabupaten Pati. Journal of Physical Education and Sports, 6(18), 198-204. https://doi.org/10.15294/JPES.V6I2.17397.

Sodik, M., Sahal, Y. F. D., \& Herlina, N. H. (2019). Pengaruh Kinerja Guru dalam Pelaksanaan Pembelajaran terhadap Prestasi Belajar Siswa pada Mata Pelajaran Alquran Hadis. Jurnal Penelitian Pendidikan Islam, 7(1), 97. https://doi.org/10.36667/jppi.v7i1.359.

Sopandi, A. (2019). Kepribadian Terhadap Kinerja Guru. Scientific Journal of Reflection, 2(2), 121-130. https://doi.org/10.5281/zenodo.2628070.

Supriyono, A. (2017). Pengaruh Kompetensi Pedagogik, Profesional, dan Motivasi Kerja terhadap Kinerja Guru Sekolah Dasar. Jurnal Pendidikan, 18(2), 1-12. https://doi.org/10.33830/jp.v18i2.269.2017.

Sya'roni, Herlambang, T., \& Cahyono, D. (2018). Dampak Motivasi, Disiplin Kerja Dan Kepemimpinan Kepala Sekolah Terhadap Kinerja Guru. Jurnal Sains Manajemen Dan Bisnis Indonesia, 8(2), 131-147. https://doi.org/10.32528/jsmbi.v8i2.1785.

Syaidah, U. (2018). Pengaruh Kompetensi Guru Terhadap Hasil Belajar Ekonomi Di Sma Negeri Rambipuji Tahun Ajaran 2017/2018. Jurnal Ilmiah Ilmu Pendidikan, Ilmu Ekonomi Dan Ilmu Sosial, 12(2), 185. https://doi.org/10.19184/jpe.v12i2.8316.

Widiansyah, A. (2018). Peranan Sumber Daya Pendidikan sebagai Faktor Penentu dalam Manajemen Sistem Pendidikan. Manajemen Sistem Pendidikan. Cakrawala, 18(2), 229-234. https://doi.org/10.31294/jc.v18i2.4347. 